Vol. 7(19), pp. 2071-2077, 7 May, 2013

DOI: $10.5897 / A J M R 12.2223$

ISSN 1996-0808 C2013 Academic Journals

African Journal of Microbiology Research

http://www.academicjournals.org/AJMR

\title{
Production of glutamic acid by Corynebacterium glutamicum using dates syrup as carbon source
}

\author{
Ahmed, Y.M. ${ }^{1,2 \star}$, Khan, J. A. ${ }^{1}$, Abulnaja, K. A. ${ }^{1}$, and Al-Malki, A. $\mathrm{L}^{1}$ \\ ${ }^{1}$ Biochemistry Department, Faculty of Science King Abdulaziz University, Jeddah, Saudi Arabia. \\ ${ }_{2}$ Microbial Biotechnology, Department, National Research Center, Dokki, Cairo, Egypt.
}

Accepted 29 March, 2013

\begin{abstract}
The present study was an illustrative investigation on L-glutamic acid production by using Corynebacterium glutamicum employing a cheaply available dates syrup. Owing to the high sugar content of dates syrup (total sugar $\mathbf{8 0} \%$ ) attempt was made to utilize the date syrup for the production of glutamic acid, in shaking culture. The acid treated dates syrup (ATDS) at concentration of $100 \mathrm{~g} / \mathrm{L}$ was the best sugar sources in the glutamic production. Penicillin addition at concentration of $4 \mathrm{U} / \mathrm{ml}$ after 12 $h$ of incubation was superior in glutamic acid production. The selected temperature-sensitive mutants M5AJ2, showed 13.4\% increase in glutamic production while, M5AJ4 and M7AJ6 showed 22.4 and $4.6 \%$ decrease respectively, in their glutamic acid production than their wild type bacterial strain. The specific production rate of glutamic acid in case of temperature shift-up from 31 to $39^{\circ} \mathrm{C}$ increased apparently 2 and 1.5 fold respectively on average from that under the constant temperature. $24 \mathrm{~g} / \mathrm{L}$ pure glutamic acid were precipitated in crystal at pH 3.2.
\end{abstract}

Key words: Glutamic acid, Corynebacterium glutamicum, dates syrup, fermentation, penicillin, mutation, UV, efflux.

\section{INTRODUCTION}

Glutamate is mainly used as a flavor agent, recently it is known as neurotransmitter, (Hawkins, 2009). It is widely used in food, pharmaceutical, medical, biochemical and analytical industries. Corynebacterium glutamicum and related organisms are used since 1957 for the production of glutamate (Kinoshita et al., 2004) to meet today an annual demand of approximately 1,500,000 tons. Over production of glutamate by $C$. glutamicum is induced by biotin limitation (Gutmann et al., 1992), or by adding specific detergents (Eggeling et al., 2001; Amin and AlTalhi, 2007) or by adding sublethal amounts of penicillin in early exponential growth phase (Numheimer et al., 1970) or at last, by a temperature up-shift of the culture broth (Delaunay et al., 1999). Glucose, and other carbon source as, beet molasses (Yoshikiro et al., 1979) and cassava residues (Jyothi et al., 2005). Later on, an investigation carried out by other agriculture wastes which are the cheap carbon source such as Muntingia calabura $L$. are used by Vijayalakshmi and Sarvamangala (2011) for the production of glutamic acid. In addition to exploitation of wild type strains for amino acid biosynthesis some workers used advanced techniques for improvement of strains by mutagenesis, cloning and protoplasm fusion techniques. Atef et al. (2007) utilized mutant cells of Brevibacterium flavum produced by UV irradiation and by ethyl methane sulfonate (EMS) treatments, increased alanine productivity. Pasha et al. (2011) tested the UV and chemical mutation for Corynebacterium glutamicum for increasing glutamic productivity.

In the present study, an attempt was made to utilize the dates syrup as carbon source, penicillin or surfactant and UV mutation to produce glutamic acid by shaking fermen- 
tation.

\section{MATERIALS AND METHODS}

\section{Microorganism}

Corynebacterium glutamicum AJ1510 obtained from Ajinomoto company was used for this study.

\section{Media}

\section{Minimal salt medium (MSM)}

It containing : 1g; $\mathrm{KH}_{2} \mathrm{PO}_{4}, 0.6 \mathrm{~g} ; \mathrm{K}_{2} \mathrm{HPO}_{4}, 1 \mathrm{~g} ;(\mathrm{NH})_{2} \mathrm{SO}_{4}, 0.5 \mathrm{~g}$; $\mathrm{MgSO}_{4} .7 \mathrm{H}_{2} \mathrm{O}$. in $1 \mathrm{~L}$ distilled water. The medium $\mathrm{pH}$ was adjusted to $\mathrm{pH}$ 7-7.5. Maintenance medium(g/l): Meat extract, 10, peptone, $10 ; \mathrm{NaCl}, 5$, agar, 20. $\mathrm{pH}$ adjusted at 7 .

\section{Fermentation medium}

For L-glutamic acid production by C. glutamicum, cells were cultured in basal salt (BS) medium per liter. Basal salt medium contained the following: $5 \mathrm{~g},\left(\mathrm{NH}_{4}\right)_{2} \mathrm{SO}_{4}, 5 \mathrm{~g}$, urea, $2 \mathrm{~g}, \mathrm{KH}_{2} \mathrm{PO}_{4}$, $2 \mathrm{~g}, \mathrm{~K}_{2} \mathrm{HPO}_{4}, 0.25 \mathrm{~g}, \mathrm{MgSO}_{4} \cdot 7 \mathrm{H}_{2} \mathrm{O}, 0.01 \mathrm{~g}, \mathrm{FeSO}_{4} \cdot 7 \mathrm{H}_{2} \mathrm{O}, 0.01 \mathrm{~g}$, $\mathrm{MnSO}_{4} \cdot 5 \mathrm{H}_{2} \mathrm{O}, 0.01 \mathrm{~g}, \mathrm{CaCl}_{2} \cdot 2 \mathrm{H}_{2} \mathrm{O}, 0.03 \mathrm{mg}, \quad \mathrm{ZnSO}_{4} \cdot 7 \mathrm{H}_{2} \mathrm{O}$, $0.1 \mathrm{mg}, \mathrm{H}_{3} \mathrm{BO}_{4}, 0.07 \mathrm{mg}, \mathrm{CoCl}_{2} \cdot 6 \mathrm{H}_{2} \mathrm{O}, 0.03 \mathrm{mg}, \mathrm{CuCl}_{2} \cdot 2 \mathrm{H}_{2} \mathrm{O}$, $0.01 \mathrm{mg}, \mathrm{NiCl}_{2}, 0.1 \mathrm{mg}$ of $\mathrm{NaMo}_{2} \mathrm{O}_{4} \cdot 2 \mathrm{H}_{2} \mathrm{O}$, different concentration of dates syrup, and $200 \mu \mathrm{l}$ of biotin $(\mathrm{pH} 7.0)$. Fifty milliliter $(50 \mathrm{ml})$ of fermentation media were added to the flasks $(250 \mathrm{ml})$. To each flask, the $1 \mathrm{ml}$ inoculums of a 24-h-old culture was added and incubated in a rotary flask shaker at $150 \mathrm{rpm}$ at $31^{\circ} \mathrm{C}$ (Hoischen et al., 1990).

\section{Mutation medium (MY)}

It contained (g/L): 10, glucose; 3, yeast extract; 3, peptone extract; 5 , malt extract; 15, agar.

\section{Treatment of dates syrup}

\section{Alkaline treatment}

The dates syrup $(10 \mathrm{~g})$ was diluted with distilled water ( 1 part $\mathrm{ml})$, the $\mathrm{pH}$ of the mixture was adjusted to $\mathrm{pH} 9.5$, and the mixture was shaking in water bath at $50^{\circ} \mathrm{C}$ for $10 \mathrm{~min}$. Then it was kept undisturbed overnight, at room temperature. The precipitate solid material was separated from the supernatant by filtration. The supernatant was neutralized to $\mathrm{pH} 7$ (Shah et al.. 2002).

\section{Acid treatment}

The dates syrup $(10 \mathrm{~g})$ was diluted with distilled water $(1$ part $\mathrm{ml})$, $0.5 \mathrm{~N}$ oxalic acid were added and heated on a boiling water bath for $3 \mathrm{~h}$. The supernatant solution was neutralized with barium carbonate then it was filtered and concentrated under vacuum to small volume, and it was added to the medium.

\section{Mutagenesis}

An aliquot of appropriate dilution of the $C$. glutamicum was grown in MY medium for $24 \mathrm{~h}$. One milliliter $(1 \mathrm{ml})$ of this culture from $C$. glutamicum cells were held in a Petri dish $20 \mathrm{~cm}$ and were exposed to UV lamp $254 \mathrm{~nm}$ at distance of $30 \mathrm{~cm}$ for 1, 2, 3, 4 and $5 \mathrm{~min}$ in a tightly closed wooden chamber. The mutated cells were plated into complex and minimal medium agar (MSM) plates and incubated for $48 \mathrm{~h}$ at $30^{\circ} \mathrm{C}$. The numbers of survivals were calculated.

\section{Analytical methods}

\section{Growth determination}

The growths of cells were determined by measuring the absorbance at $600 \mathrm{~nm}$ spectrophotometrically (Shimadzu 24016), according to the methods of Hoischen et al. (1990). Absorbency was converted to dry weight by using a standard curve.

\section{Determination of total carbohydrates}

Total carbohydrates were determined by phenol sulphuric acid method according to the study of Dubois et al. (1956) .

\section{Chromatography}

\section{Paper chromatography}

Identification of the monosaccharides and oligosaccharides for the non treated, alkaline and acid treated dates syrup were proceeded by the paper chromatoghraphic technique using Whatman No. 1 , and the solvent system n-butanol: acetic acid: water $(60: 15: 25 \mathrm{v} / \mathrm{v})$ for a period of $48 \mathrm{~h}$. The chromatogram was dried, then dipped in alkaline $-\mathrm{AgNO}_{3}$.

\section{Estimation of glutamic by thin chromatography}

The glutamic acid content in the broth after fermentation was estimated by thin chromatography using silica gel $G$ and the solvent mixture of n-butanol, glacial acetic acid and water in the ratio $4: 1: 1$ $(\mathrm{v} / \mathrm{v})$. Ninhydrine in ethanol was used to develop the colour of spots. For quantitative estimation of glutamic acid produced, the spots developed on plates were scraped and collected in microtubes which contained $5 \mathrm{ml} \mathrm{75 \%}$ ethanol (Lee, 1996). After shaking for 5 min the sample was centrifuged at $4000 \mathrm{rpm}$ and its absorbance was recorded at $560 \mathrm{~nm}$ (Lee, 1996) on UV/VIS spectrophotometer.

\section{Crystallization}

Fermented broth $(1.5 \mathrm{~L})$ collected from culturing in shaking medium was centrifuged at $10,000 \mathrm{rpm}$ for $10 \mathrm{~min}$ to get the supernatant, then the supernatant was partially evaporated in a rotary evaporator. The concentrating medium containing a high amount of glutamic acid was acidified to $\mathrm{pH} \mathrm{3.2,} \mathrm{the} \mathrm{isoelectric} \mathrm{point} \mathrm{of} \mathrm{glutamic}$ acid with $1 \mathrm{~N} \mathrm{HCl}$ and allowed to stand still in a refrigerator until the glutamic acid crystals were precipitated there from. The obtained clear crystals were identified subjected to HPLC. Glutamic acid after purification dissolved and $20 \mu / \mathrm{l}$ was applied to the HPLC, (Shimadzu, Shim-pack ISC-07/S $1504 \mathrm{Na}$, flow rate $0.3 \mathrm{ml} / \mathrm{min}$, detector-Florescence $D$ 6A). The samples were using methanol as a mobile phase at room temperature.

\section{RESULTS}

Dates syrup total sugars were determined to be about $80 \%$ according to the study of Dubois et al. (1956).

\section{Identification of the sugar content of dates syrup before and after treatment}

Different treatment were done for the dates syrup, alkali treatment was done by adjusting to $\mathrm{pH} 9.5$ after shaking water bath at $50^{\circ} \mathrm{C}$ for $10 \mathrm{~min}$, then it was kept overnight, 
Table 1. Sugar content of dates surup before and after treatment.

\begin{tabular}{llll}
\hline Sugar & Date & Alkali treatment & Acid treatment \\
\hline Mono sugar & Glucose, Fructose & Glucose, Fructose & Glucose, Fructose \\
Oligosugar & Sucrose & Sucrose & No oligosugars \\
& Other 3 oligo sugars & One oligosugars & \\
\hline
\end{tabular}

Table 2. Comparison between glucose, alkali or acid treated and non treated dates syrup in basal basal medium of $C$. glutamicum.

\begin{tabular}{|c|c|c|c|c|c|}
\hline \multirow{2}{*}{ Carbon Source } & \multicolumn{2}{|c|}{$\mathrm{pH}$} & \multirow{2}{*}{$\begin{array}{l}\text { Cells dry weight } \\
(\mathrm{g} / \mathrm{L})\end{array}$} & \multirow{2}{*}{$\begin{array}{c}\text { Consumed } \\
\text { Sugar (\%) }\end{array}$} & \multirow{2}{*}{$\begin{array}{c}\text { Glutamic acid } \\
(\mathrm{g} / \mathrm{L})\end{array}$} \\
\hline & Initial & Final & & & \\
\hline Glucose & 7.5 & 7.0 & 5.0 & 70 & 6.0 \\
\hline Non treated dates syrup & 7.5 & 6.8 & 2.3 & 40 & 3.5 \\
\hline Acid treated dates syrup & 7.5 & 7.8 & 4.35 & 80 & 8.7 \\
\hline Alkali treated dates syrup & 7.5 & 8.1 & 5.23 & 74 & 7.0 \\
\hline
\end{tabular}

the precipitate was removed by filtration and the supernatant was neutralized to $\mathrm{pH} 7$. Acid treatments were done $0.5 \mathrm{~N}$ oxalic acid for $3 \mathrm{~h}$, after neutralization with barium carbonate, the precipitate was removed by filtration. Both non treated and treated dates syrup with alkaline or acid supernatants were subject to paper chromategraphy. The data are shown in Table 1 that, the non treated, and alkali treated dates syrup contain glucose and fructose, sucrose and oligosaccharide. On the other hands, the acid treated dates syrup contained only glucoseandfructose, nosucroseoligosaccharidewasdetected.

\section{A comparison between glucose, treated and non- treated dates syrup}

In comparison between glucose, treated dates syrup by alkali or acid and non-treated dates syrup, $50 \mathrm{~g} / \mathrm{l}$ of each carbon source was added to basal medium of $C$. glutamicum. The data in Table 2, indicated that acid treated was the best sugar source in glutamic production. Good cells growth was found in both alkali dates syrup and glucose, while weak cells growth was found in non treated dates syrup.

\section{Effect of acid treated dates syrup (ATDS) concentration}

Different concentration of (ATDS) $(0,10,20,40,60,80$, 100 and 120) were added to basal medium of $C$. glutamicum as carbon source. The maximum glutamic acid was found at concentration of $100 \mathrm{~g} / \mathrm{l}$ (ATDS) then the values of percentages decreased as the concentration of dates increased as shown in Table 3.

\section{Effect of penicillin on L-glutamic acid}

In culture media of $C$. glutamicum $100 \mathrm{~g} / \mathrm{l}$ of (ATDS) replaced glucose, different units $(0-8$ units $/ \mathrm{ml})$ of penicillin were added to the media after $12 \mathrm{~h}$ of incubation time in rotary flask shaker at $150 \mathrm{rpm}$ at $31^{\circ} \mathrm{C}$, to study the optimum penicillin units for the secretion of glutamic acid.

The data obtained as shown in Table 4 indicated that supplementation of 4 units $/ \mathrm{ml}$ penicillin was superior in glutamic acid production by $C$. glutamicum than other concentrations.

\section{Induction of mutation by UV}

C. glutamicum AJ1510 (AJ) strain was exposed to UV radiation at $254 \mathrm{~nm}$ for $1,2,3,4$ and $5 \mathrm{~min}$ at a distant of $30 \mathrm{~cm}$. The results in Table 5 show a perfect negative relationship between UV- exposure time and survival percentages for bacterial strain

\section{Isolation of temperature-sensitive mutants}

Suitable dilution of each UV treatments were spread onto (MSM) medium and incubated at 40,45 and $50^{\circ} \mathrm{C}$. Colonies which showed weak growth at 40 and $45^{\circ} \mathrm{C}$, were isolated. Among 26 tested colonies, 3 strains (AJ strain) were scored as temperature sensitive mutants which showed very good growth at $30^{\circ} \mathrm{C}$.

\section{The effect of mutation on glutamic acid production}

The selected temperature-sensitive mutants $C$. glutamicum M5AJ2, M5AJ4 and M7AJ6 and their wild type bacterial strains (AJ) were cultured in basel medium, contained (ATDS) as carbon source, and incubated in shaking flask at $39^{\circ} \mathrm{C}$ to determine the effect of mutation on glutamic acid production (Table 6). Penicillin were added to culture medium after $12 \mathrm{~h}$. The selected temperature-sensitive mutants M5AJ2, showed $13.4 \%$ increase in the glutamic production while, M5AJ4 and M7AJ6 showed 22.53 and $4.6 \%$ decrease respectively, intheir glutamic acid production 
Table 3. Effect of acid treated dates syrup concentration on glutamic production by C. glutamicum.

\begin{tabular}{cccc}
\hline Dates Concentration (g/L) & Cells dry weight (g/L) & Consumed sugar (\%) & Glutamic acid (g/L) \\
\hline 0 & 0.5 & 0.0 & 0.1 \\
10 & 3.2 & 0.7 & 1.5 \\
20 & 4.3 & 1.3 & 4.8 \\
40 & 7.4 & 2.3 & 8.7 \\
60 & 8.0 & 4.4 & 10.9 \\
80 & 8.5 & 6.5 & 15.7 \\
100 & 9.55 & 7.5 & 17.9 \\
120 & 11.4 & 8.0 & 15.0 \\
\hline
\end{tabular}

Table 4. Effect of penicillin addition on glutamic acid production by C.glutamicum AJ1510.

\begin{tabular}{|c|c|c|c|c|c|}
\hline \multirow[t]{2}{*}{ Units } & \multicolumn{2}{|c|}{$\mathrm{pH}$} & \multirow{2}{*}{$\begin{array}{c}\text { Cells dry weight } \\
(\mathbf{g} / \mathbf{L})\end{array}$} & \multirow{2}{*}{$\begin{array}{c}\text { Consumed sugar } \\
(\%)\end{array}$} & \multirow{2}{*}{$\begin{array}{c}\text { Glutamic } \\
(\mathrm{g} / \mathrm{L})\end{array}$} \\
\hline & Initial & Final & & & \\
\hline 0 & 7.0 & 5.6 & 6.75 & 8.15 & 6.7 \\
\hline 2 & 7.0 & 6.8 & 7.12 & 7.7 & 8.7 \\
\hline 4 & 7.0 & 7 & 5.34 & 7.73 & 20 \\
\hline 6 & 7.0 & 7.1 & 3.38 & 8.17 & 12 \\
\hline 8 & 7.0 & 7.5 & 2.12 & 5.0 & 9.6 \\
\hline
\end{tabular}

Table 5. Effect of UV- exposure time on the survival bacteria.

\begin{tabular}{ccc}
\hline Expose time (min) & \multicolumn{2}{c}{ C. glutamicum-AJ1510 (AJ) } \\
\cline { 2 - 3 } & Cells / ml & Survival \% \\
\hline 0 & $50 \times 10^{10}$ & 100.0 \\
1 & $18 \times 10^{10}$ & 36.0 \\
2 & $12 \times 10^{8}$ & 0.24 \\
3 & $58 \times 10^{7}$ & 0.116 \\
4 & $17 \times 10^{6}$ & 0.0034 \\
5 & $13 \times 10^{6}$ & 0.0026 \\
\hline
\end{tabular}

Table 6. Glutamic acid production by some selected temperature-sensitive mutants C. glutamicum.

\begin{tabular}{|c|c|c|c|c|c|c|}
\hline \multirow{2}{*}{$\begin{array}{l}\text { Bacteria } \\
\text { Strain }\end{array}$} & \multirow[t]{2}{*}{ State } & \multicolumn{2}{|c|}{$\mathrm{pH}$} & \multirow{2}{*}{$\begin{array}{c}\text { Cells dry weight } \\
(\mathrm{g} / \mathrm{l})\end{array}$} & \multirow{2}{*}{$\begin{array}{c}\text { Residuals } \\
\text { Sugars\% }\end{array}$} & \multirow{2}{*}{$\begin{array}{c}\text { Glutamic } \\
\text { acid \% }\end{array}$} \\
\hline & & Initial & Final & & & \\
\hline$(\mathrm{AJ})$ & Wild type & 7.5 & 7.0 & $6.90 \quad 4.1$ & 0.329 & 19.6 \\
\hline M5 AJ2 & Temperature & 7.5 & 6.5 & 13.27 & 0.388 & 22.3 \\
\hline M5 AJ4 & Sensitive & 7.5 & 7.4 & 1.80 & 0.336 & 15.2 \\
\hline M7AJ6 & $\int_{\text {mutants }}$ & 7.5 & 7.2 & & 0.355 & 18.7 \\
\hline
\end{tabular}

The fermentation process achieved by basal medium. The selected temperature-sensitive mutants after exposing the wild type bacterial strains to UV

than their wild type bacterial strain. As shown in Table 6, good cells growth was found in the case of M5AJ4 than other different mutants. On the other hand, residual sugar was approximately stable.
Effect of temperature shift-up on the efflux of glutamic acid

To study the effect of temperature shift-up on the efflux of 


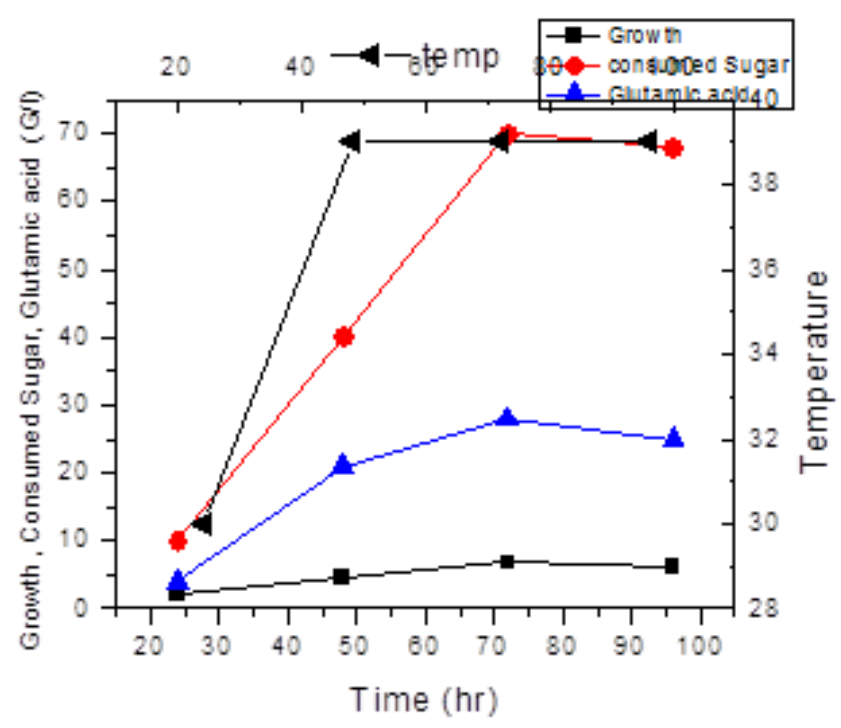

A

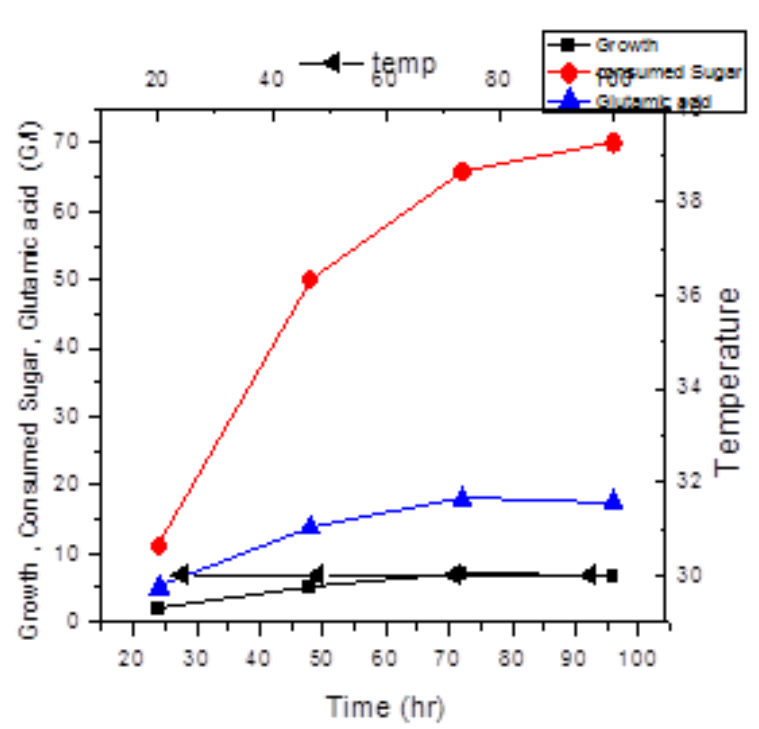

B

Figure 1. Effect of temperature shifting $\left(30\right.$ to $\left.39^{\circ} \mathrm{C}\right)$ on glutamic acid production by mutant strain; B: Effect constant temperature at $\left(30^{\circ} \mathrm{C}\right)$ on glutamic acid production by mutant strain.

glutamic acid, the mutant strain C. glutamicum M5 AJ2 and wild strain (AJ) were cultured on basal medium with (ATDS) as carbon source and 4 units $/ \mathrm{ml}$ of penicillin were added after $12 \mathrm{~h}$. The fermentation temperature was changed from 30 to $39^{\circ} \mathrm{C}$ after $24 \mathrm{~h}$ of cultivation. Both strains wild AJ and mutant strain M5 AJ2 were compared with that under constant temperature for the entire period of cultivation. The results were shown in Figures $1 \mathrm{~A}, \mathrm{~B}$ and $2 \mathrm{~A}, \mathrm{~B}$. Figures 1 and $2 \mathrm{~A}$ for mutant strain M5 AJ2 and wild strain shows that the specific production rate of glutamic acid increased apparently 2 and 1.5 fold respectively on average from that under the constant temperature.

The preliminary product identification was done qualitatively by thin layer chromatography and quantitatively by spectrophotometric analysis. The result of the former test was observed as a visible purple coloured spot having similar Rf value 0.26 similar to that of authentic standard sample. The concentration of glutamic acid was estimated by standard ninhydrin method according to the study of Lee (1996). Furthermore results of HPLC indicate the precipitated crystal at $\mathrm{pH} 3.2$ is pure glutamic acid, which about $24 \mathrm{~g} / \mathrm{l}$ glutamic acid was produced at concentration of $100 \mathrm{~g} / \mathrm{l}$ (ATDS).

\section{DISCUSSION}

The dates syrup is a very important cheap carbon source (total sugar $80 \%$ ) which can be used for the production of different important product as glutamic acid. The non treated, treated with alkaline or acid supernatants were subject to paper chromatography, the non treated dates syrup, and alkali treated contain glucose and fructose, sucrose and oligosaccharide. While, acid treated contained glucose and fructose, no sucrose oligosaccharide was detected. Although, Mostafa and Ahamed (2006) referred that, Libyan date syrup contained glucose $48.70 \%$, fructose $-45.21 \%$, and sucrose $6.09 \%$ were the major sugars. In comparison between glucose, treated dates syrup with alkali or acid and non treated dates syrup, the results indicated that acid treated was the best sugar source in glutamic production. The maximum glutamic acid and good cells growth were found at concentration of $100 \mathrm{~g} / \mathrm{l}$ (ATDS). The same results was mentioned by Das et al. (1995) who referred that glutamic acid produced from palm waste hydrolysate by fermentation with Brevibacterium lactofermentum ATCC 13869 is produced with high yield than that produced from pure glucose as a carbon source. In agreement to our results, Roy and Chatterjee (1989) referred that glucose $(8 \%)$ was the best than molasses in glutamic acid by Arthrobacter globiformis. In contrast to the results of Kyoichi et al. (1964) who found that the concentration of glutamic production by Microbacterium ammoniaphilum decrease as the concentration of glucose increased.

The data obtained as shown in Table 4 indicated that supplementation of 4 units $/ \mathrm{ml}$ penicillin was superior in glutamic acid production than other concentrations used. Penicillin primarily inhibited cell wall synthesis, leaving the cell membrane unprotected, resulting in physical damage to the cell membrane, which increase the permeability of the cell wall, then increasing glutamic secretion (Shiio et al., 1962). The effect of penicillin was also investigated on glutamic acid production by Micrococcus that the addition of $4 \mathrm{U} / \mathrm{ml}$ increase the conversion of L-homo- 


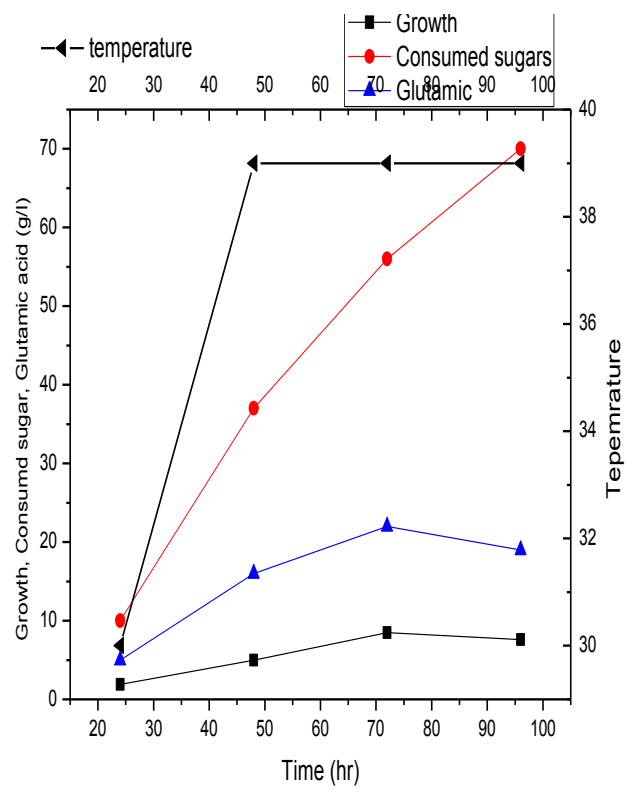

A

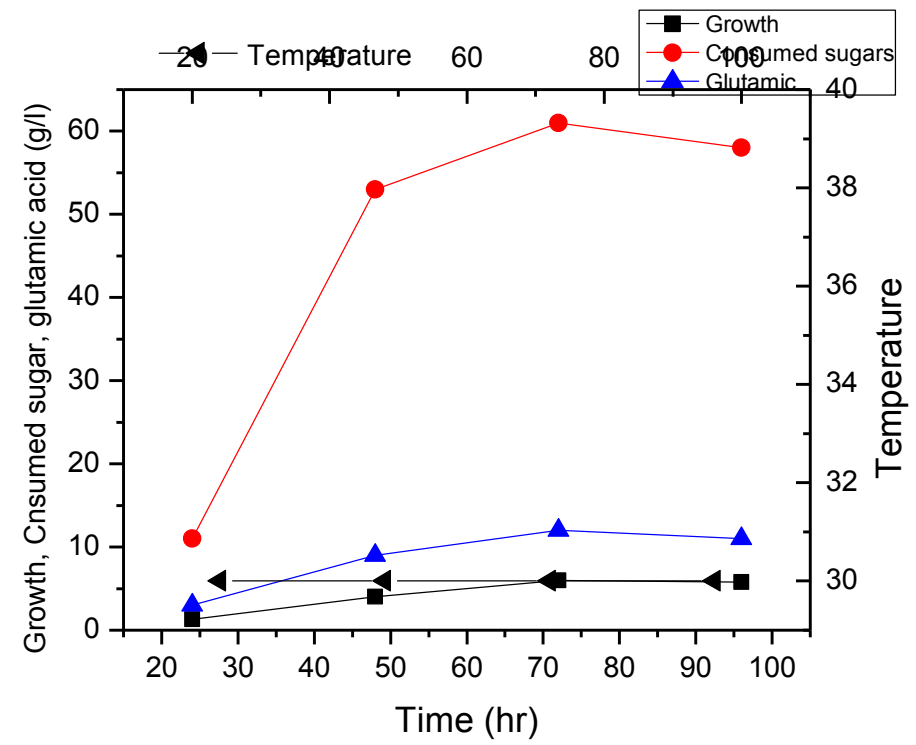

B

Figure 2. A Effect of temperature shifting $\left(30\right.$ to $\left.39^{\circ} \mathrm{C}\right)$ on glutamic acid production by wild strain; B: Effect constant temperature at $\left(30^{\circ} \mathrm{C}\right)$ on glutamic acid production by wild strain.

homoserine to L-glutamic acid production. On the other hand, Vijayalakshmi and Sarvamangala (2011), found that addition $1 \mathrm{U} / \mathrm{ml}$ to the culture medium of Arthrobacter globiformis MTCC 4299 increase the glutamic production to about $87.5 \mathrm{~g} / \mathrm{l}$. As shown in Table 5 , the survival cells decrease as the UV radiation time increase, 3 strains were scored as temperature sensitive mutants from wild strain AJ. The temperature sensitive mutants may causes higher producing ability of glutamic acid production than their wild type bacterial strain Uy et al. (2003) who, found that, at $39^{\circ} \mathrm{C}$ the glutamate was actively produced, while the activities of 2-oxoglutarate dehydrogenase complex $(\mathrm{ODHC})$ and pyruvate dehydrogenase $(\mathrm{PDH})$ were, respectively completely inhibited and 35\% decreased in their activity. The selected temperature-sensitive mutants M5AJ2, showed $13.4 \%$ increase in the glutamic production while, M5AJ4 and M7AJ6 were showed 22.5 and $4.6 \%$ decrease respectively, in their glutamic acid production than their wild type bacterial strain. The same results of the increase in the production of glutamic acid cited by Hirasawa et al. (2001) indicated that a defect caused by a mutation is responsible for temperaturesensitive growth and L-glutamate overproduction by C. glutamicum. The glutamic acid production increased to about $43 \mathrm{~g} / \mathrm{l}$ by immobilized UV mutant strains of $C$. glutamicum Pasha et al. (2011). The effect of temperature shift-up from 30 to $39^{\circ} \mathrm{C}$ through incubation were compared to that incubated at constant temperature, the results are shown in Figures 1and $2 \mathrm{~A}$ for mutant strain M5 AJ2 and wild strain shows that the specific production rate of glutamic acid increased apparently 2 and 1.5 fold respectively on average from that under the constant temperature (Figures 1 and 2B). The same results were done by Choi et al. (2004) who referred to, enhance glutamic acid production of Brevibacterium sp. with temperature shift-up cultivation from 30 to $38^{\circ} \mathrm{C}$. The concentration of glutamic acid was estimated by standard ninhydrin method (Lee, 1996).

Furthermore results of HPLC, indicate the precipitated crystal at pH 3.2 is pure glutamic acid, which about $24 \mathrm{~g} / \mathrm{l}$ glutamic acid was produced at concentration $100 \mathrm{~g} / \mathrm{l}$ (ATDS).

\section{CONCLUSION}

Owing to the high sugar content of dates syrup (total sugars $80 \%$ ), it can be used for the production of different important product as glutamic acid. By acid treated dates syrup (ATDS) only glucose and fructose were reveled by paper chromatography. In comparison between glucose, treated dates syrup with alkali or acid and non treated dates syrup, the results were indicated that acid treated was the beast sugar source in glutamic production. The optimum glutamic acid and good cells growth were found at concentration of $100 \mathrm{~g} / \mathrm{l}$ of (ATDS). Penicillin addition at concentration $4 \mathrm{U} / \mathrm{ml}$ after $12 \mathrm{~h}$ of incubation was superior in glutamic acid production. 3 mutants were scored as temperature sensitive from AJ strain. The selected temperature-sensitive mutants M5AJ2, showed 
$13.4 \%$ increase in the glutamic production while, M5AJ4 and M7AJ6 showed 22.5 and $4.6 \%$ decrease respectively, in their glutamic acid production than their wild type bacterial strain. The specific production rate of glutamic acid in case of temperature shift-up from 30 to $39^{\circ} \mathrm{C}$ increased apparently 2 and 1.5 fold respectively on average from that under the constant temperature. $24 \mathrm{~g} / \mathrm{l}$ pure glutamic acid were precipitated in crystal at pH 3.2.

\section{ACKNOWLEDGEMENTS}

This paper was funded by the Deanship of Scientific Research (DSR), King Abdulaziz University, Jeddah , under grant no (292/130/1431). The authors, therefore , acknowledge with thanks DSR technical and Financial support.

\section{REFERENCES}

Amin GA and Al-Talhi A(2007).Production of L-glutamic Acid by Immobilized Cell Reactor of the Bacterium Corynebacterium glutamicum Entrapped into Carrageenan Gel Beads. World Appl. Sci. J. $2: 62-67$.

Atef NM, Zaki DA and Abd-El-Aziz F (2007).Activation of alanine biosynthesis by Brevibacterium flavum through optimization of culture conditions, UV irradiation and EMS using low quality dates. J. Appl. Sci. Res. 3: 1950-1959.

Choi S,Takuya N and Toshiomi $\mathrm{Y}$ (2004). Enhanced glutamic acid production of Brevibacterium sp.with temperature shift-up cultivation. J. biosci. bioeng.98: 211-213.

Das K, Anis M, Azemi BM and Ismail, N(1995). Fermentation and recovery of glutamic acid from palm waste hydrolysate by lonexchange resin column. Biotech. Bioeng. 48:551-555.

Delaunay S, Uy D, Baucher MF, Engasser JM, Guyonvarch A and Goergen JL (1999). Importance of phosphoenolpyruvate carboxylase of Corynebacterium glutamicum during the temperature triggered glutamic acid fermentation. Metab. Eng. 1:334-343.

Dubois M, Gilles KA, Hamilton JK, Rebers PA and Smith F (1956). Colorimetric Method for Determination of Sugars and Related Substances. Anal. Chem. 28: 350-356

Eggeling L, Krumbach K and Sahm H (2001) L-Glutamate Efflux with Corynebacterium glutamicum:Why Is Penicillin Treatment or Tween Addition Doing the Same?.J. Mol. Microbiol. Biotechnol. 3: 67-68.

Gutmann M, Hoischen C and Krämer R (1992). Carrier-mediated glutamate secretion by Corynebacterium glutamicum under biotin limitation. Biochim Biophys Acta. 1112, 115-123.

Hawkins R A (2009).The blood-brain barrier and glutamate.Am J Clin Nutr 90:867S-74S.

Hoischen C and Krāmer R (1990). Membrane alteration is necessary but not sufficient for effective glutamate secretion in Corynebacterium glutamicum. J. Bacteriol. 172:3409-3416.

Jyothi AN, Sasikiran K, Nambisan B and Balagopalan C ( 2005). Optimization of glutamic acid production from cassava starch factory residues using Brevibacterium divaricatum. Proc. Biochem. 40: 35763579.
Kinoshita S, Udaka S and Shimono M (2004). Studies on amino acid fermentation. Part-1. Production of L-glutamic acid by various microorganism. J Gen Appl Microbiol. 50: 331-343.

Kyoichi M, Ryoji K, Isao T, Keizo G and Toru A (1964). Studies on Lglutamic acid fermentation by Microbacterium ammoniaphilum. Part II. Biotin effect on L glutamic acid production. Agr. Biol. Chem., 27: 243-248.

Lee BH (1996)Fundamentas of food Biotechnology. Montreal; VHC publishers, Inc. 324-327

Mostafa A M and Ahmed AA (2006). Libyan Date Syrup (Rub Al-Tamr) J.Food Science . 46: 1162-1174.

Nara T, Samejima H and Kinoshita S (1964). Effect of penicillin on amino acid fermentation. Agr. Biol. Chem., 28: 120-124.

Numheimer T D, Birnbaum J, Ihnen E, and Demain A L (1970). Product inhibition of the fermentative formation of glutamic acid. Appl. Microbiol., 20, 215-217.

Pasha SY, Ali MN, Tabassum H and Mohd MK(2011).Comparative studies on production of glutamic acid using wild type, mutants,immobilized cells and immobilized mutants of Corynebacterium glutamicum. Int. J. Eng. Sci. Technol. (IJEST). 3: 3941-3949.

Roy DK and Chatterjee SP (1989). Production of glutamic acid by Arthrobacter globiformis: influence of cultural conditions. Folia Microbiologica.34: 11-34.

Shah AH, Hameed A and Khan GM(2002).Improved microbial production of lysine by developing a new auxotrophic mutant of Corneybactenum glutamicum. Pakistan J. Biolog. Scie.5 : $80-83$.

Shiio I, Otsuka S and Takahashi M (1962). Effect of biotin on the bacterial formation of glutamic acid. I. Glutamate formation and cellular permeability of amino acids. J. Biochem., 51:56-62.

Uy D, Delaunay S, Germain P, Engasser J, Goergen J(2003). Instability of glutamate production by Corynebacterium glutamicum 2262 in continuous culture using the temperature-triggered process. J. Biotechnol. 104: 173-184.

Vijayalakshm P and Sarvamangala D (2011). Production of L-glutamic acid by Arthrobacter globiformis MTCC 4299 fruits of Mimusops Elengilinn. Int. J. Appl. Biol. Pharm. Technol..2:167-173. Available online at www. ijabpt.com

Yoshikiro T, Hiroe Y, Yoshio R (1979). Fermentative production of Lglutamic acid. Jpn. Kokai Tokkyo Koho JP., 78: 1994. 